九州大学学術情報リポジトリ

Kyushu University Institutional Repository

\title{
Transformation of Pseudomonas aeruginosa with Chromosomal DNA into Bacillus subtilis
}

Hara, Toshio

Laboratory of Microbial Technology, Faculty of Agriculture, Kyushu University

Ueda, Se inosuke

Laboratory of Microbial Technology, Faculty of Agriculture, Kyushu University

https://doi.org/10.5109/23746

出版情報：九州大学大学院農学研究院紀要. 26 (4)，pp.151-157，1982-07. Kyushu University バージョン：

権利関係 : 
J.Fac. Agr., Kyushu Univ., 26 (4),151-157 (1982)

\title{
Transformation of Pseudomonas aeruginosa with Chromosomal DNA into Bacillus subtilis
}

\author{
Toshio Hara and Seinosuke Ueda \\ Laboratory of Microbial Technology, Faculty of Agriculture, \\ Kyushu University 46-09, Fukuoka 812
}

(Received December 14, 1981)

\begin{abstract}
Successful transformation of gram-negative and gram-positive bacteria was achieved. Genetic transformation of Pseudomonas aeruginosa KYU-1 to Bacillus sub. tilis Marburg 168 was performed with linear chromosamal DNA, provided the cells were treated with cold calcium chloride and a heat pulse. The molecular weight of transforming DNA of the donor was markedly dependent on the transformation frequency. At $6.2 \times 10^{6}$ daltons, transformation frequency with chromosomal DNA of P. aeruginosa into B. subtilis was obtained at 2.0x10-5. The divalent ions such as $\mathrm{Ca}^{2+}$ and $\mathrm{Mg}^{2+}$ enhanced transformation frequency.
\end{abstract}

\section{INTRODUCTION}

Genetic transformation of Pseudomonas aeruginosa with linear chromosomal DNA has been reported (Khan and Sen, 1967), but this work has been proved difficult to repeat (Booker and Loutit, 1974; Sano and Kageyama, 1977). Sano and Kageyama (1977), however, reported that the $\mathrm{Ca}^{2+}$ technique was adopted to $\mathbf{P}$. a eruginosa so as to allow transformation by the DNA of the plasmid RP1 and it was also observed that $\mathrm{MgCl}_{2}$ could be used in place of $\mathrm{CaCl}_{2}$ to allow such transformation. Mercer and Loutit (1978a,b) have shown $\mathrm{Ca}^{2+}$-dependent transformation of P. aeruginosa strain 1 by the plasmid RP1 and also by DNA of the conjugative plasmid FP2. They also observed that treatment with $\mathrm{MgCl}_{2}$ allowed a restrictionless mutant of $\mathbf{P}$. aeruginosa strain 1 to be transfected by the DNA of phage F116 and transferred by purified chromosomal DNA (Mercer and Loutit, 1979).

In our previous paper (Ueda and Hara, 1981), we reported that P. aeruginosa KYU-1 produced high molecular weight DNA extracellularly. Furthermore, successful transformation of P.aeruginosa by intra- and extracellular DNA was achieved by using $\mathrm{CaCl}_{2}$ treatment in order to elucidate the nature of the extracellular DNA produced by strain KYU-1 (Hara et al., 1981).

While gene exchange appears to be common among both gram-positive and gram-negative bacteria, transformation appears to be the principal mode of gene exchange among gram-positive bacteria, such as Bacillus (Young and Wilson, 1975), and rare among the gram-negative bacteria.

We have tried to establish transformation technique between gram-positive and gram-negative bacteria. The present paper described some impor- 
tant findings.

\section{MATERIALS AND METHODS}

\section{Microorganisms}

The microorganisms used were Pseudomonas aeruginosa KYU-1 (prototroph) and Bacillus subtilis Marburg $168\left(\right.$ trp $\left.^{-}\right)$.

\section{Medium and culture conditions}

The composition of bouillon-yeast extract (BY) medium and of minimal medium were reported by Yamaguchi et al. (1974). Cells were grown in BYmedium with shaking at $30^{\circ} \mathrm{C}$ or $37^{\circ} \mathrm{C}$ as indicated.

\section{Transformation procedure}

Transforming DNA from exponentially growing cells of strain KW-1 was prepared by the method of Saito and Miura (1963). DNA was used at a saturating concentration except in those experiments when it was specifically indicated. Concentration of DNA was determined by measuring absorbance at $260 \mathrm{~nm}$.

Transformation procedure described by Cohen et al. (1972) was used. The cells of $B$. subtilis 168 were grown in BY-medium overnight at $30^{\circ} \mathrm{C}$ on a shaker. A portion $(0.2 \mathrm{ml})$ of such a culture was reinoculated in $10 \mathrm{ml}$ of a modified Spizizen's minimal medium containing L-tryptophan $(\mathbf{5 0} \mu \mathrm{g} / \mathrm{ml})$ and grown for 2.5 to $3 \mathrm{hr}$. At the late exponential phase, the cells were harvested by centrifugation and washed with $5 \mathrm{ml}$ of $10 \mathrm{mM} \mathrm{NaCl}$. The cells were again centrifuged and resuspended in $5 \mathrm{ml}$ of $\mathbf{0} .1 \mathrm{M} \mathrm{CaCl}_{2}$. The cells were kept at $0^{\circ} \mathrm{C}$ for $20 \mathrm{~min}$, harvested and resuspended in $1 \mathrm{ml}$ of $0.1 \mathrm{M}$ $\mathrm{CaCl}_{2}$. An aliquot $(0.2 \mathrm{ml})$ of these cells was afterwards mixed with $0.1 \mathrm{ml}$ of DNA solution and $0.2 \mathrm{ml}$ of $\mathrm{CaCl}_{2}$ solution and kept at $0^{\circ} \mathrm{C}$ for $60 \mathrm{~min}$. The cell-DNA mixture was then subjected to a heat pulse at $42^{\circ} \mathrm{C}$ for 2 min and chilled in ice for $5 \mathrm{~min}$. It was then diluted 10 times with fresh medium and allowed to grow overnight at $37^{\circ} \mathrm{C}$ on a shaker. $0.1 \mathrm{ml}$ of aliquot was plated on minimal medium agar plate. The plates were usually incubated for 2 to 3 days at $37^{\circ} \mathrm{C}$ before scoring the number of transformants. Transformation frequencies were calculated by the quotient of the numbers of transformants and the numbers of colony-forming units.

\section{Sucrose density gradient centrifugation}

DNA prepared by the method of Saito and Miura (1963) was centrifuged in neutral 5 to $20 \%$ linear sucrose gradient in a buffer consisting of $0.03 \mathrm{M}$ Tris- $\mathrm{HCl}(\mathrm{pH} 8.0$ ), 0.005 M EDTA and $1 \mathrm{M} \mathrm{NaCl}$. The sample was spun at $20^{\circ} \mathrm{C}$ and $84,000 \sim \mathrm{g}$ for $4 \mathrm{hr}$ in Hitachi RPS-50 rotor. The molecular weight of the DNA at the peak of absorbance was determined according to the method of van der Schans et al. (1969). 


\section{RESULTS}

\section{Effect of DNA size on transformation frequency}

The DNA samples were prepared from 5 to $20 \%$ sucrose density gradient. As shown in Table 1, transformation frequency with chromosomal DNA of $P$. aeruginosa into $B$. subtilis was markedly dependent on the molecular weight of DNA used and the frequency of transformation was $2.0 \times 10^{-5}$ when the molecular weight of DNA was $6.2 \sim 10^{6}$ daltons.

Table 1. Effect of DNA size on transformation frequency. Transformation was carried out as described in Materials and Methods. DNA of different molecular weight used was prepared by 5 to $20 \%$ sucrose density gradient at $84,000 \times g$ for $4 \mathrm{hr}$. DNA concentration used was $1.0 \mu \mathrm{g} / \mathrm{ml}$.

\begin{tabular}{cc} 
Molecular weight & Transformation frequency \\
\hline $3.7 \times 10^{6}$ & $7.4 \times 10^{-8}$ \\
$6.2 \times 10^{6}$ & $2.0 \times 10^{-5}$ \\
$1.8 \times 10^{8}$ & $4.4 \times 10^{-7}$ \\
\hline
\end{tabular}

Therefore, chromosomal DNA of molecular weight of $6.2 \sim 10^{6}$ daltons was used in this study.

\section{Effect of different concentrations of $\mathrm{CaCl}_{2}$ on transformation frequency}

Transformation of $P$. aeruginosa was achieved with chromosomal DNA by treatment with $\mathrm{CaCl}_{2}$. The optimum concentration of $\mathrm{CaCl}_{2}$ required to obtain a maximal number of transformants was determined. As shown in Fig. 1, $60 \mathrm{mM} \mathrm{CaCl}_{2}$ was optimum for outerspecific transformation. No such transfor-

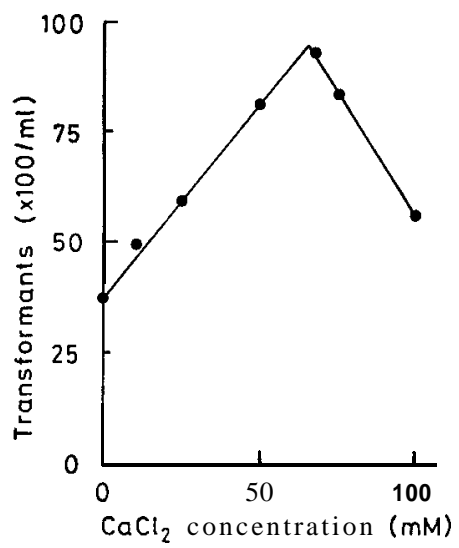

Fig. 1. Effect of various concentrations of $\mathrm{CaCl}_{2}$ on transformation frequency. $\mathrm{CaCl}_{2}$-treated cells of $\mathrm{B}$. subtilis 168 were exposed with chromosomal DNA of $P$. aeruginosa KYU-1 $(1.0 \mu \mathrm{g} / \mathrm{ml})$ for $60 \mathrm{~min}$ at $0{ }^{\circ} \mathrm{C}$. Samples were plated on minimal agar plates to select transformants for $\operatorname{trp}^{+}$and all the plates were kept overnight at $37^{\circ} \mathrm{C}$. Transformation frequency was determined by counting $\boldsymbol{t r} \boldsymbol{p}^{+}$colonies. 
mation was, of course, observed either in the absence of DNA or in the absence of $\mathrm{CaCl}_{2}$ treatment of the cells.

Henceforth, the concentration of $\mathrm{CaCl}_{2}$ used was $60 \mathrm{mM}$.

\section{Effect of DNA concentration on transformation frequency}

When the DNA concentration was varied, it was observed that transformation frequency increased with increasing concentration of DNA upto a certain limit, above which no further increase in the frequency was detected. Fig. 2 shows the response of the recipient strain B. subtilis 168 to DNA preparations from the donor strain $\mathbf{P}$. aeruginosa KYU-1. The frequency of transformation increased linearly with the increase of concentration of DNA added, and the saturating concentration of transforming DNA was reached at about $0.05 \mu \mathrm{g} / \mathrm{ml}$.

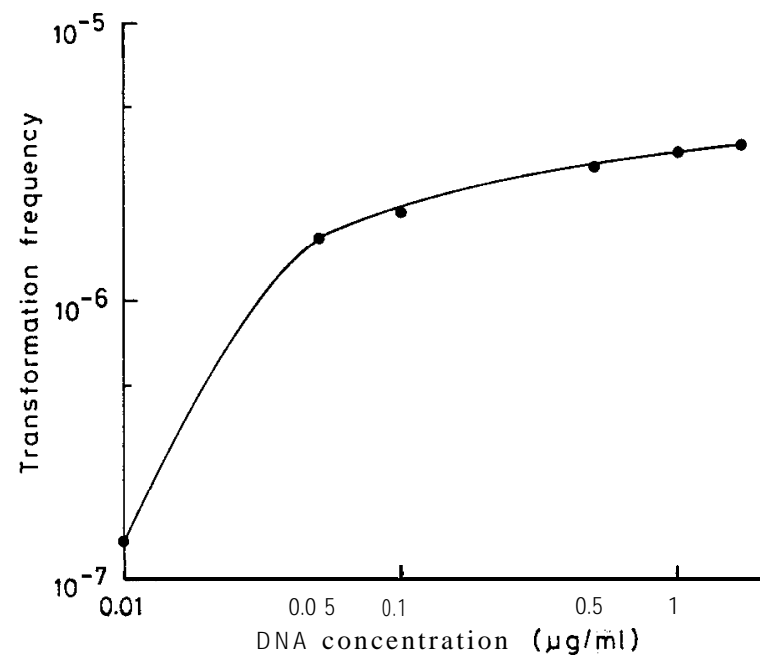

Fig. 2. Effect of DNA concentration on transformation frequency. Various concentrations of chromosomal DNA of P. aeruginosa KYU-1 were added to $\mathrm{CaCl}_{2}$-treated B. subtilis 168. Samples were plated on minimal agar plates and all the plates were kept overnight at $37^{\circ} \mathrm{C}$. Transformation frequency was determined by counting $\operatorname{trp}^{+}$colonies.

Table 2. Effect of temperature on a heat pulse. $\mathrm{CaCl}_{2}$-treated cells were treated with DNA of strain KYU-1 $(10 \mu \mathrm{g} / \mathrm{ml})$ and then subjected to a heat pulse for $2 \mathrm{~min}$ at various temperature. Transformants were plated on minimal agar plates to select for $\boldsymbol{t r}^{+}$transformants and incubated overnight at $37^{\circ} \mathrm{C}$.

Temp. $\left({ }^{\circ} \mathrm{C}\right)$

Transformation frequency

\begin{tabular}{lc}
37 & $1.5 \times 10^{-8}$ \\
40 & $9.32 .4 \times 10^{-6} 10^{-6}$ \\
42 & $1.9 \times 10-5$ \\
45 & $10^{-8}$ \\
\hline
\end{tabular}


Table 3. Effect of various periods of a heat pulse. $\mathrm{CaCl}_{2}$-treated cells were exposed with DNA $(1.0 \mu \mathrm{g} / \mathrm{ml})$ and subjected to a heat pulse at $42^{\circ} \mathrm{C}$ for various periods as indicated. Transformants were spread on minimal agar plates to select for $t r p^{+}$transformants and incubated at $37^{\circ} \mathrm{C}$.

\begin{tabular}{cc}
\hline Period $(\min )$ & Transformation frequency \\
\hline 0 & $3.4 \times 10^{-7}$ \\
1 & $5.7 \times 10^{-6}$ \\
2 & $2.0 \times 10^{-5}$ \\
3 & $7.7 \times 10^{-6}$ \\
5 & $6.8 \times 10^{-6}$ \\
\hline
\end{tabular}

\section{Effect of heat pulse on transformation frequency}

Effects of a heat pulse on transformation frequency were examined as shown in Tables 2 and 3 . Two minutes were found to be enough for the period of a heat pulse and the optimum temperature for a heat pulse ( $2 \mathrm{~min}$ ) was at $42^{\circ} \mathrm{C}$.

\section{Effect of metal ion on transformation frequency}

It was observed that the addition of $\mathrm{CaCl}_{2}$ and $\mathrm{MgCl}_{2}$ resulted in transfor . mants of only a small fraction of the recipient cells as shown in Table 4, and the considerably higher frequency of transformation was achieved after treatment with divalent metal ions such as $\mathrm{Ca}^{2+}$ and $\mathrm{Mg}^{2+}$, compared with that with other metal ions. But $\mathrm{MgSO}_{4}$ had no beneficial effect and even a single transformant was not detected.

Table 4. Effect of metal ions on transformation frequency. Cells were treated with various metal ions (each concentration $60 \mathrm{mM}$ ) as described in the text and exposed to DNA $(1.0 \mu \mathrm{g} / \mathrm{ml})$. Transformants were spread on minimal agar plates to select for $\boldsymbol{t r}^{+}$transformants and incubated overnight at $37^{\circ} \mathrm{C}$.

\begin{tabular}{lc}
\hline Metal ion & Transformation frequency \\
\hline $\mathrm{No} \mathrm{salt}_{2}$ & $10^{-8}$ \\
$\mathrm{MgCl}_{2} \cdot 2 \mathrm{H}_{2} \mathrm{O}$ & $2.0 \times 10^{-5}$ \\
$\mathrm{MgSO}_{4} \cdot 7 \mathrm{H}_{2} \mathrm{O}$ & $1.5 \times 10^{-5}$ \\
$\mathrm{MnCl}_{2}$ & $10^{-8}$ \\
$\mathrm{KCl}$ & $4.6 \times 10^{-7}$ \\
\hline
\end{tabular}

\section{DISCUSSION}

Successful transformation of gram-negative bacteria to gram-positive bacteria was achieved. One of the techniques was that of Mandel and Higa (1970), who showed that treatment with cold calcium chloride enabled Escherichiacoli to take up the purified DNA of phages lambda and P2 and to produce viable phage. Recent work has shown that purified plasmid DNA and chromosomal DNA will also transform E. coli after cold $\mathrm{CaCl}_{2}$ treatment (Cohen 
et al., 1972; Cosloy and Oishi, 1973).

Genetic transformation of E. coli and Salmonella typhimurium has been demonstrated with plasmid DNA, provided the cells were treated with $\mathrm{CaCl}_{2}$ to make them permeable to the naked DNA (Cohen et al., 1972: Lederberg and Cohen, 1974) and also with chromosomal DNA, provided the E. coli cells additionally lacked ATP-dependent DNase and exonuclease I (Oishi and Cosloy, 1972).

Pseudomonas putida (Chakrabarty et al., 1975; Johnston and Gunsalus, 1977) is a gram-negative bacterium, which has been demonstrated to undergo both transductional and conjugational gene exchange with other members of the species. In a recent report (Sano and Kageyama, 1977), the $\mathrm{Ca}^{2+}$ technique was adopted to $P$. aeruginosa so as to allow transformation by the DNA of the plasmid RP1. Furthermore, $\mathrm{Ca}^{2+}$-dependent transformation of $P$. aeruginosa by purified chromosomal DNA was performed (Mercer and Loutit, 1978a; Mylroie et al., 1978).

We performed the DNA-mediated transformation of $P$. aeruginosa and $B$. subtilis, provided the cells were treated with $\mathrm{CaCl}_{2}$ and a heat pulse. At this time, the molecular weight of DNA of the donor was greatly dependent on the frequency of transformation. When the molecular weight of transforming DNA was $6.2 \sim 10^{6}$ daltons.

Mercer and Loutit (197813) observed that treatment with $\mathrm{MgCl}_{2}$ allowed a restrictionless mutant of $P$. aeruginosa strain 1 to be transformed by purified chromosomal DNA. In a subsequent report (Mercer and Loutit,1979), they reported that $\mathrm{CaCl}_{2}, \mathrm{MgCl}_{2}$ and $\mathrm{MnCl}_{2}$ were found to promote transformation of $P$. aeruginosa.

In the case of $P$. aeruginosa KYU-1, transformation was achieved with chromosomal DNA after treated with $\mathrm{CaCl}_{2}$ or $\mathrm{MgCl}_{2}$, but no such transformation was observed when $\mathrm{MnCl}_{2}$ was used. At that time, $\mathrm{CaCl}_{2}$ treatment and a heat pulse were necessary for the transformation of Pseudomonas, but if any of these procedures was omitted, no transformant could be detected.

\section{REFERENCES}

Booker, R. J. and J. S. Loutit 1974 The order of replication of chromosomal markers in Pseudomonas aeruginosa 1. I. Marker frequency analysis by transduction. Genet. Res., 23 : 145-153

Chakrabarty, A. M., J. R. Mylroie. D. A. Friello and J. G. Vacca 1975 Transformation of Pseudomonas putida and Escherichia coli with plasmid-linked drug-resistance factor DNA. Proc. Natl. Acad. Sci. U.S.A., 72: 3647-3651

Cohen, S. N., A. C. Y. Chang and L. Hsu 1972 Nonchromosomal antibiotic resistance in bacteria: genetic transformation of Escherichia coli by R-factor DNA. Proc. Natl. Acad. Sci. U.S.A., 60: 2110-2114

Cosloy. S. D. and M. Oishi 1973 The nature of the transformation process in Escherichia coli K12. Mol. Gen. Genet., 124: I-10

Hara, T., A. Aumayr and S. Ueda 1981 Genetic transformation of Pseudomonas aeruginosa with extracellular DNA. J. Gen. Appl.Microbiol., 27: 109-114

Johnston, J. B. and I. C. Gunsalus 1977 Isolation of metabolic plasmid DNA from Pseudo- 
monas putida. Biochem. Biophys. Res. Commun., 75: 13-19

Khan, N. C. and S. P. Sen 1967 Genetic transformation in Pseudomonas. J. Gen. Microbiol., 49 : 201-209

Lederberg, E. M. and S. N. Cohen 1974 Transformation of Salmonella typhimurium by plasmid deoxyribonucleic acid. J. Bacteriol, 119: 1072-1074

Mandel, M. and A. Higa 1970 Calcium-dependent bacteriophage DNA infection. J. Mol. Biol., 53: 159-162

Mercer, A. A. and J. S.Loutit 1978 a Transformation of Pseudomonas aeruginosa by DNA of the conjugative plasmid FP2. Proc. Univ. Otago Med. Sch., 56: 19-20

Mercer, A. A. and J. S. Loutit 1978b Transformation and transfection of Pseudomonas aeruginosa with linear DNA. Proc. Univ. 0 tago Med. Sch., 56: 56-57

Mercer, A. A. and J. S. Loutit 1979 Transformation and transfection of Pseudomonas aeruginosa: effects of metal ions. J.Bacteriol., 140: 37-42

Mylroie, J. R., D. A. Friello and A. M. Chakrabarty 1978 Transformation of Pseudomonas putida with chromosomal DNA. Biochem. Biophys. Res. Commun., 82: 281-288

Oishi, M. and S. D. Cosloy 1972 The genetic and biochemical basis of the transformability of Escherichia coli.Biochem. Biophys. Res. Commun., 49: 1568-1572

Saito, H. and K. Miura 1963 Preparation of transforming deoxyribonucleic acid by phenol treatment. Biochim. Biophys. Acta,72: 619-629

Sano, Y. and M. Kageyama 1977 Transformation of Pseudomonas aeruginosa by plasmid DNA. J. Gen. Appl.Microbiol., 23: $183-186$

Schans, G. P. van der, J. B. T. Aten and J. Blok 1969 Determination of molecular weight distributions of DNA by means of sedimentation in a sucrose gradient. Anal. Biochem.. 32: $14-30$

Ueda, S. and T. Hara 1981 Studies on nucleic acids production and application. Part I. Production of extracellular DNA by Pseudomonas sp. KYU-1. J. Appt. Biochem., 3: 1-10

Yamaguchi, K., Y. Nagata and B. Maruo 1974 Isolation of mutants defective in $\alpha$-amylase from Bacillus subtilis. J. Bacteriol., 119 : $\mathbf{4 1 0 - 4 1 5}$

Young, F. E. and G. A. Wilson 1975 Chromosomal map of Bacillus subtilis. In "Spores VI," ed. by P. Gerhardt, R. N. Costilow and H. L. Sadoff, American Society for Microbiology, Washington, D.C., p. 596-614 